\title{
Syphilis screening using the multi-channel blood-grouping machine
}

\author{
J. W. LOCKYER, B.Sc. \\ S.W. Regional Transfusion Centre, Southmead, Bristol BS10 5ND
}

Automated syphilis testing was introduced by Pugh and Gaze (1965) when they successfully demonstrated that the Wassermann reaction could be incorporated into an auto-analyser system.

Norins (1968) described a method for performing ar. automated flocculation test for syphilis using a multi-channel blood-grouping machine. This involved the use of a VDRL antigen in the presence of fine carbon particles which permitted gross visualization of a positive reaction against the white background of the machine filter paper.

At the South-West Regional Blood Transfusion Centre, Bristol, we have for several years been using a multi-channel blood-grouping machine for the routine daily testing of between 500 and 700 donor bloods. We were therefore anxious to include within its programme an automated syphilis screening test.

Within a transfusion centre, the method described by Norins has a distinct advantage over that of Pugh and Gaze in that it permits the syphilis test to be carried out alongside routine $\mathrm{ABO}$ and Rhesus grouping, using a non-heated, unclotted sample. Norins' method was given a short trial in this laboratory with favourable results, but because of the high cost of carbon antigen and the difficulty in obtaining continued supplies, the test had to be abandoned and research was started to provide an alternative method.

Two established manual methods for syphilis screening have now been successfully incorporated into a multi-channel blood-grouping machine: the modified Laughlen flocculation test, using a Kahn antigen coupled with a scarlet red stain, and a Wassermann complement-fixation technique, using a cardiolipin antigen.

\section{Modified Laughlen flocculation test EQUIPMENT}

A standard Technicon fully-automated fifteen-channel blood-grouping machine with a sampling ratio of 120 per hour was used throughout the experiment. Serum was sampled for 8 seconds followed by a saline wash of 19 seconds.

Received for publication: November 24, 1969

\section{BLOOD SAMPLES}

$4 \mathrm{ml}$. donor blood was taken into $1 \mathrm{ml}$. standard blood transfusion anticoagulant consisting of 2.08 per cent. disodium citrate and 2.5 per cent. dextrose. The majority of samples were tested on the day following their collection; but those taken on a Friday were not normally tested until the following Monday morning.

PREPARATION OF THE LAUGHLEN ANTIGEN

(1) Place $450 \mathrm{ml}$. 1.5 per cent. saline is a clean stoppered vessel and warm in a water bath at $50^{\circ} \mathrm{C}$. for $30 \mathrm{~min}$.

(2) Into a second clean dry vessel put $45 \mathrm{ml}$. standard Kahn antigen (Staynes Laboratories) and $200 \mathrm{mg}$. scarlet red powder. Immerse in the water bath at $50^{\circ} \mathrm{C}$. for $5 \mathrm{~min}$.

(3) To the warmed antigen/stain mixture add $1 \mathrm{ml}$. Tincture of Benzoin Co. to act as an antigen stabiliser. Mix rapidly.

(4) Remove the warmed saline from the water bath and rapidly wipe away any excess water from the outside of the vessel. Pour the saline into the antigen stain mixture. Mix thoroughly by pouring from one vessel to another four times.

(5) Replace in water bath at $50^{\circ} \mathrm{C}$. for $5 \mathrm{~min}$.

(6) Allow to stand at normal room temperature for 20 min. and syphon off the supernatant into a clean dry bottle, leaving a few $\mathrm{ml}$. of undissolved stain at the bottom of the vessel.

(7) Add $5 \mathrm{ml}$. saturated ammonium sulphate to enhance antigen sensitivity. Mix thoroughly.

(8) Store the antigen for $48 \mathrm{hrs}$ at normal room temperature and for a further 5 days at $4^{\circ} \mathrm{C}$. It is then ready for use.

(9) Store at $4^{\circ} \mathrm{C}$. when not in use.

(10) When in use the antigen should be kept in even suspension by using a low speed magnetic stirrer.

The sensitivity of this antigen is considerably enhanced when allowed to ripen for 6 to 7 days before use. Once prepared it is stable for up to 6 weeks.

\section{TEST PROCEDURE}

The flow diagram (Fig. 1) shows the method used for the Laughlen test. Donors' unheated plasma is mixed with the Laughlen antigen in the proportion of two volumes of plasma to one of antigen. Air is introduced to segment the specimen which then moves into a 48-turn mixing coil with a 7-minute incubation time at room temperature; 


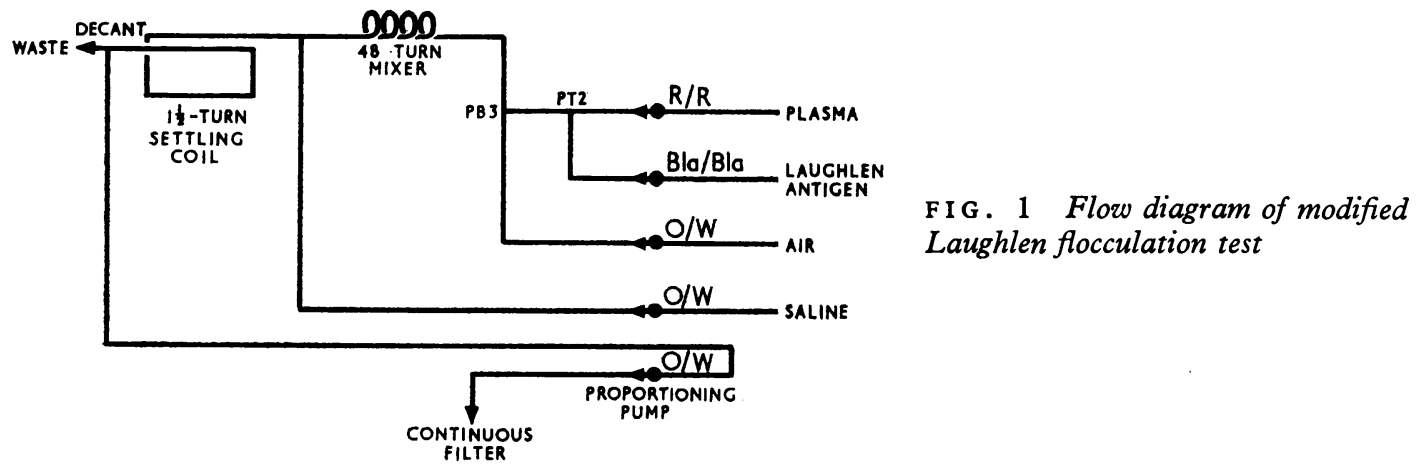

saline is then injected into the system allowing the floccules to settle more readily. The mixture passes into a $1 \frac{1}{2}$-turn settling coil and on to a T-type decant junction where the floccules are drawn off and deposited on to the white filter paper recorder roll as a red precipitate. The total time from plasma syphoning to recording is $12 \frac{1}{2}$ minutes.

At the beginning and end of each day's work it is necessary to put through a strong and weak positive control. The result of each donor test is then read off against the control and recorded as strong positive, weak positive, or negative.

\section{Results of tests}

The automated results were evaluated against a manual VDRL precipitation and Wassermann complement-fixation test. Those found to be positive by either one or both of the tests were forwarded to the Public Health Laboratories where a Reiter protein complement-fixation test was carried out in addition to a Wassermann complement-fixation test. 13,800 donor bloods were included within this initial trial.

The Table shows an analysis of the 13,800 samples tested. Of these 13,759 gave negative results by both automated and manual methods, the remaining 41 giving a positive result by one or more of the manual or automated methods. The Table shows that the results fall clearly into one of seven different patterns. Eight samples gave positive results by both the manual and automated methods, although only two of these were confirmed as positive by the Public Health Laboratory. Nine samples gave positive results by the Laughlen machine test and negative results by the manual methods: these were all later confirmed as negative.

In summarizing the chief findings, it is seen that, when testing 13,800 donor bloods, 26 gave a positive machine Laughlen test of which only three were confirmed as positive by the Public Health Laboratory. In comparing this false-positive figure of 26 with the 41 found by one or both of the applied manual screening methods, it would appear that the automated technique would reduce the number of false-positive screening tests. The Table shows that the Laughlen machine test was negative in fifteen cases which gave a positive result by one or both of the manual methods, and that these were all confirmed as negative by the Reiter protein complement-fixation test.

\section{Modified automated complement-fixation Wassermann reaction}

Whilst Pugh and Gaze (1965) successfully demonstrated that the Wassermann reaction could be adapted

TABLE Analysis of 41 positive donor syphilis screening tests

\begin{tabular}{|c|c|c|c|c|c|}
\hline \multirow[t]{2}{*}{$\begin{array}{l}\text { Number } \\
\text { positive }\end{array}$} & \multicolumn{2}{|l|}{ Manual } & \multirow{2}{*}{$\begin{array}{l}\text { Automated } \\
\text { Laughlen } \\
\text { flocculation }\end{array}$} & \multicolumn{2}{|c|}{$\begin{array}{l}\text { Public Health Laboratory confirmation by } \\
\text { Reiter protein complement-fixation }\end{array}$} \\
\hline & $V D R L$ & $\begin{array}{l}\text { Wassermann } \\
\text { complement-fixation }\end{array}$ & & Positive & Negative \\
\hline 7 & + & 0 & + & 1 & 6 \\
\hline 2 & 0 & + & + & 0 & 2 \\
\hline 4 & 0 & + & 0 & 0 & 4 \\
\hline 9 & 0 & 0 & + & 0 & 9 \\
\hline 2 & + & + & 0 & 0 & 2 \\
\hline
\end{tabular}


to an auto-analyser system, no effort has so far been made to apply a complement-fixation test to the blood-grouping machine. The main hazard is the need for the test to be performed on a citrated unheated plasma void of free calcium and magnesium, both necessary to complete a haemolytic reaction successfully. In addition, the blood-grouping machine has no colorimetric or recording apparatus for measuring haemolysis. In attempting to overcome these difficulties it was shown that heat inactivation of the free complement present in approximately 50 per cent. of the citrated machine blood samples could be obtained by heating it to $56^{\circ}-58^{\circ} \mathrm{C}$. for as little as 1 minute. Many previous workers have shown that normal serum complement levels can be destroyed by heating serum at $60^{\circ} \mathrm{C}$. for 3 minutes. By reducing time and temperature to 1 minute and $58^{\circ} \mathrm{C}$. respectively, the small amount of free complement remaining can be satisfactorily inactivated. The problem of supplying additional calcium and magnesium was readily overcome, since the standard buffer solution used in the preparation of the cardiolipin antigen contains both of these substances, thereby enabling the sub-fractions of complement to combine.

Preliminary studies were carried out on donor plasma treated as in Fig. 2.

The plasma was passed through a heating coil at $56-58^{\circ} \mathrm{C}$. and mixed first with cardiolipin antigen and then with complement; it was then allowed 5 min. incubation at $37^{\circ} \mathrm{C}$. in a mixing coil. Sensitized sheep cells were then injected into the system and a further $5 \mathrm{~min}$. were allowed at $37^{\circ} \mathrm{C}$.

It was shown that haemolysis of these sensitized cells could be quite satisfactorily brought about in all donor plasma where the manual screening test was negative. The syphilis positive plasma fails to lyse the sensitized sheep cells because of the binding of the complement, and they remain as free non-haemolysed cells. Therefore negative syphilis plasma results appear on the filter paper recorder as a haemolysed cell droplet, whilst the syphilis positive plasma appears as non-haemolysed free cells. Unfortunately in this form it is almost impossible to differentiate a negative from a positive result. To overcome this a potent anti-sheep red cell agglutinin is injected into the system at the end of the second incubation coil. This produces strong agglutination in the positive cases in which no lysis of cells would occur. By applying this procedure the negative test appears as a haemolysed drop, whilst the positive appears as strong agglutinates. As with the Laughlen test a strong and weak positive control should be put through at the beginning and end of each day's testing.

Our trial studies have so far proved most encouraging and we have now started a routine daily procedure of testing our donor plasma by both the Laughlen flocculation test and the complement-fixation test.

As with all complement-fixation tests, the dilution of the guinea-pig complement is critical: should it be incorrectly prepared, too concentrated or too dilute, this will quickly show itself when the controls are put through. No lysis with negative samples indicates insufficient complement, whilst lysis in the case of the positive control will suggest that the complement requires further dilution.

\section{ANTI-COMPLEMENTARY PLASMA}

It is to be expected that a very small proportion ( 1 to 2 per cent.) of specimens of donor plasma will have a strong anti-complementary activity, such a plasma will appear on the filter paper record as a positive test, and this would call for a manual repeat including the usual anti-complementary controls.

\section{Reagents for the modified complement-fixation test} CARDIOLIPIN ANTIGEN (prepared fresh each day)

$1 \mathrm{ml}$. cardiolipin antigen (Wellcome Maltaner) is diluted with $149 \mathrm{ml}$. complement-fixation buffer (Oxoid). This is preferred to isotonic saline as it contains both calcium and magnesium salts.

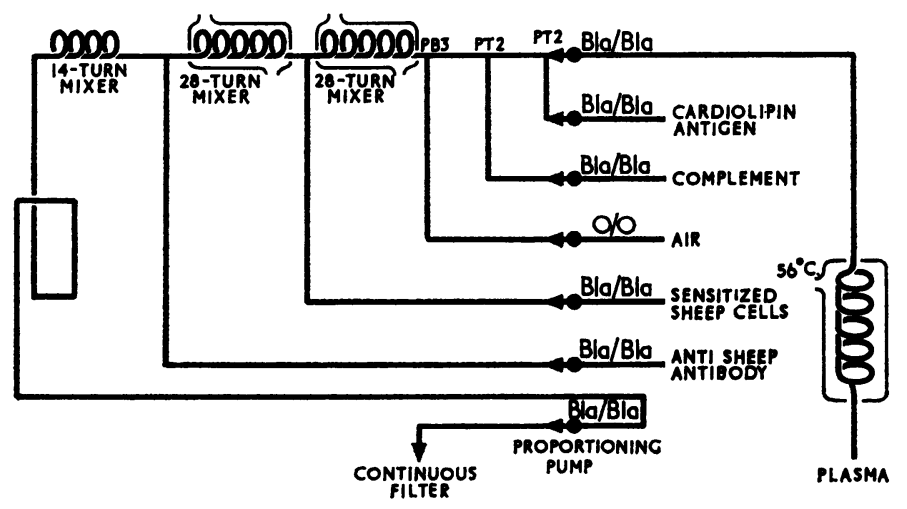

FI G. 2 Flow diagram of modified Wassermann complement-fixation test 


\section{COMPLEMENT}

Preserved guinea-pig serum (Burroughs Wellcome Laboratories) prepared fresh each day. The minimum haemolytic dose for use was determined by performing the standard technique used in complement-fixation tests.

\section{SENSITIZED SHEEP CELLS}

$150 \mathrm{ml}$. complement-fixation test buffer is added to $1 \mathrm{ml}$. haemolytic horse anti-sheep serum (Staynes Laboratories) together with $3.5 \mathrm{ml}$. washed concentrated sheep cells. Mix thoroughly and incubate at $37^{\circ} \mathrm{C}$. for 1 hour. The cells are then ready for immediate use; they should be kept in even suspension using a low-speed magnetic stirrer.

\section{ANTI-SHEEP CELL AGGLUTINATOR}

Anti-sheep agglutinating serum should be used at a dilution which gives a strong visual reaction within 30 sec. when tested against sensitized sheep cells by a manual method. To obtain this avidity time it is often necessary to dilute the anti-sheep agglutinin in a 1 per cent. bromelin solution.

Sheep red cell agglutinating antibody can be obtained commercially or produced by immunizing one's own laboratory rabbits. Certain plant extracts, including a preparation from potatoes, show strong agglutinating activity against sheep cells (Pardoe, Bird, and Uhlenbruck, 1969). Preliminary studies with this material have proved most encouraging, and such a substance might well replace the rabbit and horse anti-sheep agglutinators.

\section{Cost of reagents and additional staff require- ment for automating 2,500 donor syphilis screening tests \\ LAUGHLEN TEST}

As this calls for nothing more than a standard Kahn antigen ( $45 \mathrm{ml}$. for $450 \mathrm{ml}$. prepared antigen) the test can be carried out for as little as $0 \cdot 3$ penny per sample.

\section{COMPLEMENT-FIXATION TEST}

This requires $5 \mathrm{ml}$. cardiolipin antigen, $25 \mathrm{ml}$. preserved guinea-pig complement, $20 \mathrm{ml}$. sheep cells, and $15 \mathrm{ml}$. anti-sheep serum, giving a sampling cost of 1.4 pence per test. This figure could be easily reduced to 0.8 penny per test by substituting a suitable plant extract for the anti-sheep agglutinator.

\section{STAFFING}

This would call for an extra student technician on the machine for approximately 3 hours per day, whose duties would be to prepare the standard reagents and confirm by manual technique any machine positive results. These costs would have to be offset against the saving of staff released from the manual syphilis screening department.

\section{Summary}

Two completely automated syphilis screening tests suitable for programming into the Technicon multi- channel blood-grouping machine have been described.

(1) A modified Laughlen flocculation test which uses a non-heated citrated donor plasma against a standard Kahn antigen coupled with a scarlet red stain. The positive sera give a distinctly strong positive reaction which appears on the white recorder filter paper as a red precipitate. The test can be incorporated into the machine at a very low cost with the minimum of extra equipment. Maximum reagent costing for each sample is 0.3 of a penny.

(2) A slightly more involved method is based on the Wassermann complement-fixation reaction. Complement inactivation is effected by passing each plasma through a small heat inactivation coil at a temperature of $56-58^{\circ} \mathrm{C}$. for $1 \mathrm{~min}$. This proved adequate for eliminating the activity of the small amount of complement present. Heated plasma is then mixed first with a cardiolipin antigen, and then with a controlled amount of diluted guinea-pig complement. After incubation at $37^{\circ} \mathrm{C}$. sensitized sheep cells are added. After a further short incubation, a strong anti-sheep red cell agglutinator is injected into the system, to bring about agglutination of those sheep cells not haemolysed by the plasma from positive specimens. This permits simple differentiation of the positives as agglutinated cells from the negative tests which will appear as a haemolysed drop. The complement-fixation technique again calls for the minimum of additional equipment; reagent costs can be as low as 0.8 of a penny per sample.

With the Laughlen test sufficient antigen for a month's supply can be produced at one preparation and stored at $4^{\circ} \mathrm{C}$. The reagent preparation time for the complement-fixation test is approximately 1 hour, and reagents should be prepared freshly each day.

The minimum of additional student technician staff is required. The only extra work involved, beyond the routine for $\mathrm{ABO}$ and Rhesus grouping within the machine, would be the preparation of the sypilis screening reagents and the manual confirmation of any automated positive results.

I wish to thank Dr. G. H. Tovey, Director of this Laboratory, for his advice and guidance with both the practical and theoretical work involved in the preparation of this paper, also Mr. R. Cotton, Scientific Officer supervising automation within this Centre, for preparing the manifolds (particularly the heat inactivation coil) and for assistance in many other ways, and Mr. Christopher Darke for his guidance on complement inactivation and for preparing the flow diagrams. 


\section{References}

NoRINS, L. C. (1968) 'The Automation of Serologic Tests for Syphilis and Gonorrhea', in 'Automation in Analytical Chemistry: Technicon Symposia, 1967', vol. 1, p. 157. Mediad Incorporated, White Plains, New York

Pardoe, G. I., Bird, G. W. G., and Uhlendruck, G. (1969) Z. Immun.-Forsch., 137, 442

Pugh, V. W., and GAzE, R. W. T. (1965) Brit. F. vener. Dis., 41, 221

\begin{tabular}{|c|c|}
\hline & \\
\hline Glass Mixing Coils & $\begin{array}{l}\text { Technicon Instrument Co., } \\
\text { Hanworth Lane, } \\
\text { Chertsey, Surrey. }\end{array}$ \\
\hline $\begin{array}{l}\text { T.E.P. Motorised Pump Unit } \\
\text { (model 175) }\end{array}$ & $\begin{array}{l}\text { Scienco Westerns Limited, } \\
11-13 \text { Roundstone Street, } \\
\text { Trowbridge, Wilts. }\end{array}$ \\
\hline $\begin{array}{l}\text { Cardiolipin Antigen and Guinea- } \\
\text { pig Preserved Complement }\end{array}$ & $\begin{array}{l}\text { Burroughs Wellcome Laboratories, } \\
\text { Beckenham, } \\
\text { Kent. }\end{array}$ \\
\hline $\begin{array}{l}\text { Kahn Antigen and Horse Haemo- } \\
\text { lytic Anti-Sheep Serum } \\
\text { Sheep Cells } \\
\text { Scarlet Red Stain }\end{array}$ & $\begin{array}{l}\text { Staynes Laboratories, } \\
\text { High Wycombe, } \\
\text { Bucks. } \\
\text { G. T. Gurr, } \\
\text { London, S.W.6. }\end{array}$ \\
\hline
\end{tabular}

Dépistage de la syphilis par utilisation d'une machine à canaux multiples pour la détermination des groupes sanguins

\section{SOMMAIRE}

On décrit deux dispositifs entièrement automatiques de dépistage de la syphilis pouvant être pratiqués avec une machine Technicon à plusieurs canaux, telle qu'elle est employée pour la recherche des groupes sanguins.

$1^{\circ}$ )-Un test de floculation Laughlen modifié met en présence le plasma citraté non chauffé du donneur avec l'antigène Kahn standard couplé avec un colorant rouge écarlate. Les sérums positifs donnent une réaction nettement reconnaissable sous forme d'un précipité rouge sur le blanc du papier-filtre receveur. L'épreuve peut être introduite dans la machine à très bas prix, avec un minimum d'équipement supplémentaire. Le coût maximum des réactifs pour chaque sérum est de 0,3 penny.

$2^{\circ}$ )-Une méthode légèrement plus compliquée concerne la réaction de fixation du complément de Wassermann. L'inactivation du complément est effectuée en passant pour une minute chaque plasma dans un petit cylindre chauffant inactivant, à la température de $56 / 58^{\circ} \mathrm{C}$. Ceci convient pour inactiver la petite quantité de complément présente. Le plasma ainsi chauffé est alors mélangé d'abord avec l'antigène cardiolipidique puis avec une quantité adjustée de complément de cobaye diluée. Après incubation à $37^{\circ} \mathrm{C}$, on ajoute les globules de mouton sensibilisés. Après une nouvelle et brève incubation, on introduit un agglutinateur puissant des globules antimouton dans le dispositif, afin d'agglutiner les cellules de mouton qui n'ont pas été hémolysées par le plasma des échantillons positifs. La différenciation des échantillons positifs est facile parce que les résultats négatifs apparaissent sous forme d'une tache hémolysée. Pour la technique de la fixation du complément, il faut un minimum d'équipement supplémentaire; le coût des réactifs peut être aussi bas que 0,8 penny par sérum.

Pour l'épreuve Laughlen, une quantité suffisante d'antigène pour un mois peut être produite en une seule opération et conservée à $4^{\circ} \mathrm{C}$. Pour l'épreuve de fixation du complément, la durée d'utilisation utile du réactif est d'environ une heure et les réactifs doivent être reprépareés chaque jour.

Les opérations demandent un supplément minimum de temps d'un étudiant technicien. Le travail supplémentaire, par rapport à celui de la routine pour la détermination des groupes sanguins et du facteur Rhésus, est la préparation des réactifs de dépistage de la syphilis et la confirmation manuelle de chacun des résultats positifs obtenus par la machine. 